Article

\title{
Honey Extracts Exhibit Cytoprotective Properties against UVB-Induced Photodamage in Human Experimental Skin Models
}

\author{
Athanasios Karapetsas ${ }^{1}$, Georgia-Persephoni Voulgaridou ${ }^{1} \mathbb{D}$, Dimitra Iliadi ${ }^{1}$, \\ Ilias Tsochantaridis ${ }^{1}$, Panagiota Michail ${ }^{1}$, Spyridon Kynigopoulos ${ }^{2}$, Maria Lambropoulou ${ }^{2}{ }^{(1)}$, \\ Maria-Ioanna Stavropoulou ${ }^{3}$, Konstantina Stathopoulou ${ }^{3}$, Sofia Karabournioti ${ }^{4}$, \\ Nektarios Aligiannis ${ }^{3}$, Konstantinos Gardikis ${ }^{5}$, Alex Galanis ${ }^{1}$ (D), Mihalis I. Panayiotidis ${ }^{6,7}$ (D) \\ and Aglaia Pappa ${ }^{1, *}$ \\ 1 Department of Molecular Biology \& Genetics, Democritus University of Thrace, 68100 Alexandroupolis, \\ Greece; karapetsas_than@yahoo.gr (A.K.); georgiavou_85@hotmail.com (G.-P.V.); \\ dimitrailiadi@gmail.com (D.I.); iliatsoc@gmail.com (I.T.); peny_mich@hotmail.com (P.M.); \\ agalanis@mbg.duth.gr (A.G.) \\ 2 Laboratory of Histology and Embryology, School of Medicine, Faculty of Health Sciences, \\ Democritus University of Thrace, 68100 Alexandroupolis, Greece; spyroskinigopoulos@hotmail.com (S.K.); \\ mlambro@med.duth.gr (M.L.) \\ 3 Department of Pharmacy, Division of Pharmacognosy \& Natural Products Chemistry, University of Athens, \\ 15771 Athens, Greece; mstavropoul@yahoo.gr (M.-I.S.); kstatho@pharm.uoa.gr (K.S.); \\ aligiannis@pharm.uoa.gr (N.A.) \\ 4 Attiki-Pittas, Department of Quality Assurance, 15771 Athens, Greece; scar@attiki-pittas.gr \\ 5 APIVITA SA, Industrial Park, Markopoulo, 19003 Athens, Greece; gardikis-k@apivita.com \\ 6 Department of Electron Microscopy \& Molecular Pathology, The Cyprus Institute of Neurology \& Genetics, \\ Nicosia 2371, Cyprus; mihalisp@cing.ac.cy \\ 7 The Cyprus School of Molecular Medicine, Nicosia 1683, Cyprus \\ * Correspondence: apappa@mbg.duth.gr; Tel.: +30-25510-30625
}

Received: 20 May 2020; Accepted: 23 June 2020; Published: 30 June 2020

\begin{abstract}
In the present study, we aimed to examine the antioxidant, antiaging and photoprotective properties of Greek honey samples of various botanical and geographical origin. Ethyl-acetate extracts were used and the and the total phenolic/flavonoid content and antioxidant capacity were evaluated. Honey extracts were then studied for their cytoprotective properties against UVB-induced photodamage using human immortalized keratinocytes (HaCaT) and/or reconstituted human skin tissue models. Specifically, the cytotoxicity, oxidative status, DNA damage and gene expression levels of specific matrix metalloproteinases (MMPs) were examined. Overall, the treatment of HaCaT cells with honey extracts resulted in lower levels of DNA strand breaks and attenuated the decrease in cell viability following UVB exposure. Additionally, honey extracts significantly decreased the total protein carbonyl content of the irradiated cells, however, they had no significant effect on their total antioxidant status. Finally, the extracts alleviated the UVB-induced up-regulation of MMPs-3, -7 and -9 in a model of reconstituted skin tissue. In conclusion, honey extracts exhibited significant photoprotective and antiaging properties under UVB exposure conditions and thus could be further exploited as promising agents for developing novel and naturally-based, antiaging cosmeceutical products.
\end{abstract}

Keywords: honey; antiaging; antioxidant; photoprotective; ultraviolet radiation (UV); DNA damage; matrix metalloproteinases (MMPs); HaCaT; 3D reconstituted skin model 


\section{Introduction}

Human skin is the largest multifunctional organ of the body, and it plays a pivotal role in temperature regulation, detection of environmental stimuli, and in protecting the body against external biological, chemical and physical stressors [1-3]. Serving as a physical barrier, skin is constantly exposed to a wide range of environmental agents such as microbes, irritants, allergens, pollutants and ultraviolet (UV) radiation. Specifically, UV radiation can have detrimental effects on skin homeostasis such as erythema and immunosuppression, and it has also been associated with skin aging and carcinogenesis [4].

UV can be subdivided into three main categories according to wavelength: UVC (200-290 nm), UVB (290-320 nm) and UVA (320-400 nm) [5]. While UVC is the most damaging type of UV radiation, it is mainly absorbed by the ozone layer of the atmosphere and thus does not reach the earth's surface. On the contrary, UVB is only partially absorbed by the ozone layer, therefore, it reaches the skin epidermis, while UVA can penetrate deeper into the skin dermis as it is not absorbed by the atmosphere [6,7].

UV is strongly linked to skin aging through various molecular and cellular mechanisms [8]. Particularly, UVB radiation is the most detrimental radiation for the epidermal basal layer as it directly induces the formation of UV-induced DNA photoproducts with the most prominent ones being cyclobutane pyrimidine dimmers (CPDs) and pyrimidine 6-4 pyrimidines [9]. These photolesions can inhibit DNA replication and transcription and therefore generate permanent mutations, which subsequently lead to cell death, photoaging and photocarcinogenesis [10]. Moreover, UVB irradiation is linked to collagen degradation through inhibition of pro-collagen biosynthesis and up-regulation of matrix metalloproteinases (MMPs) [11]. These are calcium-dependent enzymes that play a key role in tissue remodelling and extracellular matrix degradation [12]. Additionally, UVA and UVB interfere with the skin aging process through the generation of reactive oxygen species (ROS) [13]. Increased ROS levels lead to oxidative stress and cause damages to biomolecules, such as proteins, DNA and lipids [14]. Hence, the development of cosmeceuticals products with photoprotective, antioxidative and antiaging properties is fundamental for the prevention of the hazardous effects of UV exposure.

Since ancient times, honey is well-known for its therapeutic potential [15]. In recent years, there is a tremendous interest in related potent bioactivities, antiseptic and/or health-promoting properties [16]. Honey is a concentrated aqueous solution of inverted sugars, mainly glucose and fructose, which contains a variety of amino and organic acids, vitamins, minerals and antioxidants. It is rich in flavonoids (apigenin, quercetin, galangin, kaempferol, pinocembrin, acacetin), phenolic acids (caffeic acid, gallic acid), caffeic acid phenethyl ester (CAPE) and carotenoids [16]. Different types of honey exhibit wide variations in their composition as a result of the diversity of bee species and their foraging strategies, as well as differences in weather conditions and botanical sources at the collection sites [17,18].

Several studies have indicated the antibacterial [18-26], antioxidant [21-24,26-30], antifungal [18,21], antimicrobial $[21,24,25,27,28,30]$, anti-inflammatory $[18,19,21-28,30]$, antitumor $[18,21,22,26-28]$, immunomodulatory [18,19,21,24-28,30] and antiproliferative [21,22,26-28] potential of honey. The antioxidant properties of honey are mostly attributed to its organic acids [24] as well as to its phenolic components, which are mainly flavonoid compounds [16,21,22]. Honey could exert its antioxidant activity through scavenging ROS, elevating the intracellular levels of glutathione (GSH), beta-carotene, uric acid and vitamin C, donating hydrogen and chelating metallic ion [23,31]). The phenolic content of honey is also related to its anti-ulcerous, anti-inflammatory, and anti-bacterial properties [24,27,32]. Specifically, certain phenolic ingredients of honey inhibit the nitric oxide synthase, inducible nitric axide synthase (iNOS) and cyclooxygenase-2 (COX-2) activities. Furthermore, the anti-ulcerous properties of honey phenolic compounds are attributed to their ability to enhance the prostaglandin content of the mucosa as well as to suppress acid secretion. Additionally, chrysin, a significant flavonoid component of honey, was found to protect human HaCaT keratinocytes against UVA and UVB-induced DNA damage, ROS generation and apoptosis, as well as inhibit UV-dependent 
up-regulation of COX-2 in HaCaT cells. Moreover, anticancer and antimetastatic properties have also been reported [26,33].

However, few reports are available on the photoprotective qualities of honey against UV-related photoaging. The goal of this study was to investigate the protective effects of Greek-origin honey extracts against UVB, which causes the most severe damaging effects in the epidermal skin layer [34,35]. Therefore, samples of honey from various botanical origin and geographic regions of Greece were collected and extracted. The extracts were examined initially for their phenolic and flavonoid content and in vitro antioxidant activity. Then, the cytotoxicity, oxidative status, DNA damage and gene expression levels of specific MMPs were examined under UVB exposure conditions in both human immortalized keratinocytes (HaCaT) and reconstituted skin tissues (EpidermTM EPI-200).

\section{Materials and Methods}

\subsection{Honey Collection, Melissopalynological Analysis, Extraction and Processing}

Five honey samples were collected from various regions of Greece on different seasons (Table 1). They were subjected to melisopalinological analysis according to the method of Von der Ohe et al. [36]. Ten grams ( $10 \mathrm{~g}$ ) of each honey sample was diluted in $20 \mathrm{~mL}$ of distilled water and centrifuged at $3000 \mathrm{rpm}$ for $10 \mathrm{~min}$. The sediment was dried at $40{ }^{\circ} \mathrm{C}$ and mounted with Entellan Rapid (Merck, Kenilworth, NJ, USA, 1.07961.0500). Pollen grains (800-1000) were counted and identified in two different slides at 200× magnifications using an OLYMPUS BX 40 light microscope. Phenolic compound extraction and purification steps were performed as described previously [37]. Samples were thoroughly

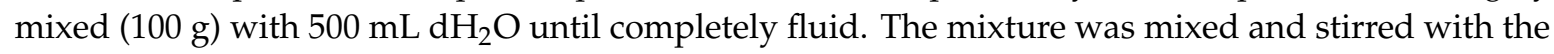
non-ionic macroreticular adsorbent resin XAD-4 at RT for $15 \mathrm{~h}$ to obtain the phenolic components, which are responsible for the antioxidant activity. The solution was filtered under vacuum and the resin was washed with $\mathrm{dH}_{2} \mathrm{O}$ to remove sugars. The phenolic compounds absorbed in the resin were eluted with methanol. Since significant amount of sugars were still contained in the phenolic extracts, they were concentrated, dissolved in $\mathrm{dH}_{2} \mathrm{O}$ and forwarded to extraction with ethyl acetate $(3 \times 50 \mathrm{~mL})$. The ethyl acetate extracts were forwarded for evaluation of their phenolic and flavonoid content as well as for their cell-free antioxidant activity. The most promising extracts were further examined for their photoprotective potential.

Table 1. Geographic origin and season of harvest of honey samples used in the study.

\begin{tabular}{|c|c|c|c|}
\hline Honey Extract & Pollen Analysis & Origin & Year of Harvest \\
\hline ME1.3 & $\begin{array}{c}\text { Compositae } 44 \% \\
\text { Thymus capitatus } 21 \% \\
\text { Eucalyptus sp. } 11 \% \\
\text { Centaurea sp. } 8 \% \\
\text { Trifollium sp. } 7 \% \\
\text { Liliaceae } 4 \% \\
\text { Erica sp. } 2 \% \\
\text { Umbeliferae } 1 \% \\
\text { Nectarless: Olea europaea, } \\
\text { Cistus } \text { Helianthemum }\end{array}$ & Chania, Crete & 2012 \\
\hline ME5.3 & $\begin{array}{l}\text { Polygonum aviculare. 38\% } \\
\text { Rhamnus sp. } 19 \% \\
\text { Quercus ilex } 19 \% \\
\text { Brassica sp. } 19 \% \\
\text { Compositae 3\% }\end{array}$ & $\begin{array}{c}\text { Vytina, } \\
\text { Peloponnese }\end{array}$ & 2012 \\
\hline
\end{tabular}


Table 1. Cont.

\begin{tabular}{|c|c|c|c|}
\hline Honey Extract & Pollen Analysis & Origin & Year of Harvest \\
\hline ME11.2 & $\begin{array}{c}\text { Abies sp. } 27 \% \\
\text { Rosaceae } 27 \% \\
\text { Quercus ilex } 18 \% \\
\text { Trifollium sp. } 9 \% \\
\text { Arbutus sp. } 4.5 \% \\
\text { Umbeliferae } 4.5 \% \\
\text { Castanea sativa } 4.5 \% \\
\text { Ramnus sp. } 4.5 \% \\
\text { Nectarless: Cistus sp., } \\
\text { Olea europaea } \\
\text { Centaurea sp. } 33 \%\end{array}$ & $\begin{array}{c}\text { Feneos, } \\
\text { Peloponnese }\end{array}$ & 2014 \\
\hline ME16.1 & $\begin{array}{c}\text { Compositae } 16 \% \\
\text { Ceratonia siliqua } 11 \% \\
\text { Quercus ilex } 11 \% \\
\text { Lonicera } \mathrm{sp} .11 \% \\
\text { Citrus } \mathrm{sp} .11 \% \\
\text { Rubus sp. } 5.5 \%\end{array}$ & Chania, Crete & 2014 \\
\hline 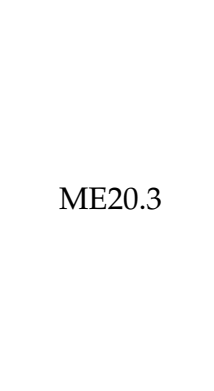 & $\begin{array}{c}\text { Nectarless: Cistus sp., } \\
\text { Convolvulus sp., Olea europaea } \\
\text { Trifollium sp. } 3 \% \\
\text { Carduus sp. } 4 \% \\
\text { Mentha sp. } 4 \% \\
\text { Abies sp. } 9 \% \\
\text { Thymus sp. } 6 \% \\
\text { Nectarless: Quercus sp., } \\
\text { Cistus sp., Olea europaea, } \\
\text { Hypericum sp., Rosaceae }\end{array}$ & $\begin{array}{l}\text { Mt. Olympus } \\
\text { National Park }\end{array}$ & 2014 \\
\hline
\end{tabular}

(sp.: species).

\subsection{Assessment of Total Phenolic Content (TPC)}

The total phenolic content of honey extracts was calculated through the Folin-Ciocalteu method $[38,39]$. Particularly, either $25 \mu \mathrm{L}$ of honey extracts or standard solution of gallic acid $(2.5,5,10,12.5,20$, $25,40,50,80,100 \mu \mathrm{g} / \mathrm{mL}$ ) diluted in DMSO were added to $125 \mu \mathrm{L}$ of $10 \%$ Folin-Ciocalteu solution. Subsequently, $100 \mu \mathrm{L}$ of $7.5 \%$ sodium carbonate were added in a 96-well plate. The samples were incubated for $30 \mathrm{~min}$ at room temperature in dark. Measurement of the absorbance and estimation of the TPC expressed as mg gallic acid equivalents (GAE) per gram of dry extract were performed as described previously [40].

\subsection{Assessment of Total Flavonoid Content (TFC)}

The aluminium chloride colorimetric assay was used for the evaluation of the TFC of honey extracts [41] and was carried out as described previously [40].

2.4. Evaluation of Cell-Free Antioxidant Activity through ABTS (2,2'-Azino-bis(3-Ethylbenzothiazoline-6Sulfonic Acid) and DPPH (2,2-Diphenyl-1-Picrylhydrazil) Assays

The radical scavenging activity of honey extracts was estimated by the ABTS and the DPPH assays as described previously [40,42-44]. Based on the values derived from the percentage inhibition of the radical for each extract, reference curves were plotted for each extract. From these curves (extract concentration-inhibition \%) the $\mathrm{IC}_{50}(\mu \mathrm{g} / \mathrm{mL})$ values were calculated. $\mathrm{IC}_{50}$ (half maximal inhibitory concentration) value corresponds to the sample concentration that can scavenge $50 \%$ of the DPPH radical and is inversely proportional to the antioxidant/radical scavenging of the sample. Gallic acid was used as positive control. 


\subsection{Cell Culture}

The immortalized human skin keratinocyte (HaCaT) cell line was purchased from the American Type Culture Collection (ATCC, Rockville, USA) and cultured in Dulbecco's modified Eagle's medium (DMEM) high glucose, enriched with 10\% foetal bovine serum (FBS), $100 \mathrm{U} / \mathrm{mL}$ penicillin and $100 \mu \mathrm{g} / \mathrm{mL}$ streptomycin (all were supplied by Biosera, Boussens, France), at $37^{\circ} \mathrm{C}, 5 \% v / v \mathrm{CO}_{2}$, in a humidified atmosphere. Honey extracts were dissolved in DMSO and then diluted in culture medium. In all treatments, cells (60-70\% confluency) were incubated with honey extracts for $2 \mathrm{~h}$, followed by UVB exposure $\left(55 \mathrm{~mJ} / \mathrm{cm}^{2}\right)$, then treated with honey extracts for $2 \mathrm{~h}$, and finally recovered in complete medium for $24 \mathrm{~h}$. Cell viability was assessed by trypan blue exclusion assay.

\subsection{Sulforhodamine B (SRB) Assay}

The cytotoxicity profile of honey extracts was assessed by the SRB assay as described previously [40]. In brief, $5 \times 10^{3} \mathrm{HaCaT}$ cells per well were cultured in 96-well microplates. After $24 \mathrm{~h}$, cells were incubated with increasing concentrations of honey extracts $(0-200 \mu \mathrm{g} / \mathrm{mL})$ for $24 \mathrm{~h}$ and then fixed by $50 \%(w / v)$ ice-cold trichloroacetic acid (TCA) and stained with $0.4 \%(w / v)$ SRB dye in $1 \%(v / v)$ acetic acid. Finally, the bound dye was dissolved in $10 \mathrm{mM}$ Tris base and the absorbance was monitored at $570 \mathrm{~nm}$ by a multi-plate reader (Tecan, Mannedorf, Switzerland). The percent (\%) cell viability was calculated using the formula:

$$
\left[\left(\text { Sample } \mathrm{OD}_{570} \text { - media blank } \mathrm{OD}_{570}\right)\right] /\left[\left(\text { mean control } \mathrm{OD}_{570}-\text { media blank } \mathrm{OD}_{570}\right)\right] \times 100
$$

The $\mathrm{EC}_{50}$ values (effective concentration that induces $50 \%$ decrease in cell viability) were calculated by Sigma Plot Software v.10 (Systat, San Jose, CA, USA) via a four-parameter logistic curve. The correlation of ABTS values with TPC honey extract levels was examined by Pearson coefficient correlation with Graph Pad Prism.

\subsection{Single Cell Gel Electrophoresis Assay/Comet Assay}

For comet assay, $3 \times 10^{5} \mathrm{HaCaT}$ cells were plated in $60 \mathrm{~mm}$ plates, cultured for $24 \mathrm{~h}$ and then incubated in the presence or absence of honey extracts $(20 \mu \mathrm{g} / \mathrm{mL})$ diluted in cell culture medium for $2 \mathrm{~h}$. Following incubation, keratinocytes were washed and irradiated by UVB $\left(55 \mathrm{~mJ} / \mathrm{cm}^{2}\right)$ in PBS (Biosera) using a UV Stratalinker 1800 (Stratagene, La Jolla, CA, USA) or left untreated. Both treated and untreated cells were further incubated with $20 \mu \mathrm{g} / \mathrm{mL}$ honey extracts diluted in culture medium or with normal culture medium for $2 \mathrm{~h}$ and then allowed to recover for $24 \mathrm{~h}$ in culture medium. Subsequently, cells were collected with trypsinization and comet assay was performed as described previously $[40,45]$.

\subsection{Determination of Antioxidant Capacity in Cell Lysates}

The Cayman's Antioxidant Assay kit (Cayman Chemical, Ann Arbor, MI, USA) was used for the estimation of the antioxidant capacity of $\mathrm{HaCaT}$ cell lysates according to manufacturer's instructions and as described previously [40]. In brief, $2.5 \times 10^{6} \mathrm{HaCaT}$ cells were cultured for $24 \mathrm{~h}$ and incubated with or without $20 \mu \mathrm{g} / \mathrm{mL}$ of honey extracts diluted in cell culture medium for $2 \mathrm{~h}$. Then, the HaCaT cells were UVB irradiated $\left(55 \mathrm{~mJ} / \mathrm{cm}^{2}\right)$ in PBS by using a UV Stratalinker 1800 (Stratagene, La Jolla, CA, USA) or left untreated. The cells were further incubated for $2 \mathrm{~h}$ in culture medium with or without honey extracts $(20 \mu \mathrm{g} / \mathrm{mL})$ and then allowed to recover in culture medium for $24 \mathrm{~h}$. Finally, the cells were collected and lysed and processed for the evaluation of the antioxidant capacity, which was expressed as $\mathrm{mM}$ Trolox Equivalents. 


\subsection{Assessment of Protein Carbonyl Content}

For the assessment of protein oxidation, the Protein Carbonyl Colorimetric Assay kit (Cayman Chemical, Ann Arbor, MI, USA) was used to measure the levels of protein-bound carbonyl groups. This assay is related to the reaction of 2,4-dinitrophenylhydrazine (DNPH) with protein carbonyls resulting in the production and detection of hydrazone at $370 \mathrm{~nm}$. In summary, $2.5 \times 10^{6} \mathrm{HaCaT}$ cells were plated in $100 \mathrm{~mm}$ plates $24 \mathrm{~h}$ prior to the experiment. Then, keratinocytes were cultured in the presence or absence of honey extracts $(20 \mu \mathrm{g} / \mathrm{mL})$ for $2 \mathrm{~h}$, washed with PBS, and irradiated by UVB $\left(55 \mathrm{~mJ} / \mathrm{cm}^{2}\right)$ or left untreated. The cells were then treated with or without $20 \mu \mathrm{g} / \mathrm{mL} \mathrm{of}$ honey extracts for $2 \mathrm{~h}$ and recovered for $24 \mathrm{~h}$ in culture medium. Finally, the cells were collected and processed for the assessment of protein carbonyl content as previously described [40]. Protein concentration was measured by using bicinchoninic acid (BCA) protein assay kit according to the manufacturer's instructions.

\subsection{Human Reconstituted Skin Tissue Model (EpiDerm ${ }^{T M}$ EPI-200)}

Epiderm $^{\mathrm{TM}}$ EPI-200 (MatTek Inc. Ellicot City MA, USA), supplied as 24-well culture plates inserts with each specific insert plate containing skin tissue, is a human reconstituted skin model. More specifically, it is a normal, human 3D model of epidermal tissue, which contains neonatal-derived human keratinocytes. These cells were isolated, cultured and differentiated in order to form the layers of epidermis. In addition, these reconstituted epidermal tissues are metabolically and mitotic active, imitating the human skin properties [46]. They are cultured in specific designed plates so that the upper surface of tissues (stratum corneum) is exposed to air, whereas the under surface is exposed to the medium. Skin tissues were equilibrated in EPI-100 assay medium at $37^{\circ} \mathrm{C}$ for $24 \mathrm{~h}$ under normal moisture conditions containing 5\% v/v $\mathrm{CO}_{2}$ and then maintained in the same medium. During the experiment, the Epiderm ${ }^{\mathrm{TM}}$ EPI-200 epidermal tissues were cultured in 6-well plates that contained the medium. Thus, stratum corneum of skin tissues was exposed to air, whereas the stratum basale was exposed to EPI-100 assay medium.

\subsection{Treatment and UVB Irradiation of EpiDerm ${ }^{T M}$ EPI-200}

The upper surface of Epiderm ${ }^{\mathrm{TM}}$ EPI-200 skin tissues were pre-treated with honey extracts $(20 \mu \mathrm{g} / \mathrm{mL}$ diluted in EPI-100 assay medium) for $2 \mathrm{~h}$ and then rinsed with $1 \times \mathrm{PBS}(\times 3)$. Subsequently, epidermal tissues (cultured in $1 \times$ PBS) were irradiated with UVB radiation $\left(55 \mathrm{~mJ} / \mathrm{cm}^{2}\right)$ and then topically treated with honey extracts for $2 \mathrm{~h}$. Finally, the specific insert plates with reconstituted tissues were cultured in fresh EPI-100 assay medium and collected $24 \mathrm{~h}$ post-UVB irradiation for processing with immunohistochemistry and real-time PCR.

\subsection{Quantitative Real-Time PCR}

Total RNA was extracted from skin tissues using the Trizol reagent (Life Technologies, Thermo Fischer Scientific, Waltham, USA) in line with the manufacturer's instructions. Five microliters $(5 \mu \mathrm{L})$ of total RNA was reverse-transcribed into cDNA using the Superscript First-Strand Synthesis Kit for Real Time Polymerase Chain Reaction (RT-PCR) (Life Technologies). Real-time PCR experiments were performed on a StepOne PCR system in MicroAmp ${ }^{\circledR}$ Fast Optical 48-Well Reaction Plates (Thermo Fisher Scientific) using the KAPA SYBR ${ }^{\circledR}$ FAST qPCR Kit (Kapa Biosystems, Wilmington, NC, USA). The PCR program included the following steps: $3 \mathrm{~min}$ at $95^{\circ} \mathrm{C}$ followed by 40 cycles at $95{ }^{\circ} \mathrm{C}$ for $15 \mathrm{~s}$ and at $60^{\circ} \mathrm{C}$ for $1 \mathrm{~min}$. Following PCR, melting curve analysis was performed in order to detect the presence of by-products and/or primer dimmers. For the quantification of transcripts, the $\Delta \Delta \mathrm{Ct}$ method was used. Particularly, the difference in the expression of a gene equals $2^{-\Delta \Delta \mathrm{Ct}}, \mathrm{where} \Delta \mathrm{Ct}$ equals the difference between the $\mathrm{Ct}$ of the test gene and the reporter gene (in that case the $\beta$-actin) and $\Delta \Delta \mathrm{Ct}$ equals the difference between $\Delta \mathrm{Ct}$ of each sample and the $\Delta \mathrm{Ct}$ of the control. All the reactions 
were carried out in triplicates and the sequences of $M M P-1, M M P-3, M M P-7, M M P-9$ and $\beta$-actin primers are shown in Table 2.

Table 2. The primers used for real-time PCR.

\begin{tabular}{ccc}
\hline Gene & Forward Primer $\left(\mathbf{5}^{\prime} \boldsymbol{\rightarrow} \mathbf{3}^{\prime} \mathbf{)}\right.$ & $\mathbf{R e v e r s e}$ Primer $\left(\mathbf{5}^{\prime} \rightarrow \mathbf{3}^{\prime}\right)$ \\
\hline$M M P-1$ & CCTCGCTGGGAGCAAACA & TTGGCAAATCTGGCGTGTAA \\
$M M P-3$ & GAGGCATCCACACCCTAGGTT & ATCAGAAATGGCTGCATCGAT \\
$M M P-7$ & CTGCATTTCAGGAAAGTTGTATGG & AGCTCCTCGCGCAAAGC \\
$M M P-9$ & GGACGATGCCTGCAACGT & CAAATACAGCTGGTTCCCAATCT \\
$\beta$-actin & GCGCGGCTACAGCTTCA & CTTAATGTCACGCACGATTTCC \\
\hline
\end{tabular}

\subsection{Immunohistochemistry (IHC)}

Histopathological examination was performed on $4 \mathrm{~mm}$ tissue sections after haematoxylin and eosin (H\&E) staining as described before [40]. To detect MMP-1, MMP-3, MMP-7 and MMP-9, Epiderm ${ }^{\mathrm{TM}}$ EPI-200 skin tissues were collected $24 \mathrm{~h}$-post UVB irradiation, fixed in formalin and embedded in paraffin. Next, the sections (size: $2 \mu \mathrm{m}$ ) were deparaffinized, rehydrated and treated for 5 min with $0.3 \%$ $\mathrm{H}_{2} \mathrm{O}_{2}$ in methanol preventing the endogenous peroxidase activity. These sections were subsequently immunostained with the peroxidase method (Envision System, DAKO, Carpinteria, CA, USA) in line with the manufacturer's instructions. In short, the sections were blocked with protein block serum-free (DAKO) post-antigen reacquisition and endogenous peroxidase blocking. They were incubated with monoclonal or polyclonal antibodies, specifically for MMP-1 (mouse-raised, 1:750 dilution), MMP-3 (rabbit-raised, 1:100 dilution), MMP-9 (mouse-raised, 1:900 dilution) (all were supplied by Acris Herford, Germany) and MMP-7 (rabbit-raised, 1:100 dilution) (Proteintech, Manchester, UK) at $4{ }^{\circ} \mathrm{C}$, overnight. Then, the sections were incubated with the corresponding secondary antibodies for $1 \mathrm{~h}$ at $\mathrm{RT}$, the antibody complexes were dyed with 3, $3^{\prime}$-diaminobenzidine (DAB) solution $(0.05 \%)$, and finally sections were counterstained with Mayer's haematoxylin. Sections were then mounted and visualized under a Nikon Eclipse 50i microtome. Control samples were incubated without mouse or rabbit immunization serum (negative control) and the results were assessed in a blinded fashion by an expert and independent pathologist according to the percentage of positively-stained cells in the entire section of each sample. Specifically, a semi-quantitively system was applied for scoring the specimens on a scale of 0 to 3: negative (0) for sections with $>10 \%$ positively stained cells; low (1) for sections with $10-20 \%$ stained cells; moderate (2) for $20-50 \%$ positively stained cells; and high for $>50 \%$ stained cells. Intensity was not separately scored.

\subsection{Statistical Analysis}

Sigma Plot Software v.10 as well as GraphPad Prism 5 were used for the creation of graphs and the statistical analysis. The results are expressed as the mean of $\pm \mathrm{SD}$ of at least three independent experiments, which were carried out in triplicates. Statistical analysis between controls and treatments were performed by ANOVA followed by Tukey's $t$-test. A $p \leq 0.05$ was considered as statistically significant. The correlation of ABTS values with TPC honey extract levels was examined by Pearson coefficient correlation with Graph Pad Prism.

\section{Results}

\subsection{Chemical Characterization, Assessment of Radical Scavenging Activity and Cytotoxicity Profile of Honey Extracts}

Honey samples were collected from various geographic regions of Greece (Table 1) and extracted with ethyl-acetate (a total of five extracts) (Table 1). The TPC and TFC values of the honey extracts were then evaluated. As shown in Table 3, honey extracts exhibited versatile TPC and TFC, ranging between 78.1 to $101.3 \mathrm{mg}$ GAE/g of dry extract and 6.7 to $30.3 \mathrm{mg} \mathrm{QE} / \mathrm{g}$ of dry extract for TPC and 
TFC, respectively. Furthermore, the radical scavenging activity of honey extracts was evaluated by the cell-free ABTS and DPPH methods. As shown in Table 4, honey extracts exhibited scavenging activity, varying between $22.8-25.8 \%$ and $55.5-67 \%$ inhibition against $\mathrm{ABTS}^{\bullet+}$ and $\mathrm{DPPH}^{\bullet}$ radical formation, respectively. The $\mathrm{IC}_{50}$ values (regarding $\mathrm{DPPH}$ scavenging activity) for all samples were higher than $200 \mu \mathrm{g} / \mathrm{mL}$, while the $\mathrm{IC}_{50}$ for gallic acid (used as positive control) was $4.5 \pm 0.08 \mu \mathrm{g} / \mathrm{mL}$.

Table 3. Total phenolic content (TPC) and total flavonoid content (TFC) of honey extracts (C = $0.1 \mathrm{mg} / \mathrm{mL})$.

\begin{tabular}{ccc}
\hline \multirow{2}{*}{ Honey Extract } & $\begin{array}{c}\text { TPC } \\
\text { mg GAE/g Extract }\end{array}$ & $\begin{array}{c}\text { TFC } \\
\text { mg QE/g Extract }\end{array}$ \\
\hline ME1.3 & $101.30 \pm 11.20$ & $30.3 \pm 4.32$ \\
ME5.3 & $84.60 \pm 9.10$ & $9.6 \pm 1.23$ \\
ME11.2 & $85.30 \pm 6.00$ & $6.7 \pm 2.88$ \\
ME16.1 & $78.10 \pm 12.50$ & $8.4 \pm 0.75$ \\
ME20.3 & $94.40 \pm 9.80$ & $9.1 \pm 0.88$
\end{tabular}

TPC and TFC values are expressed as mg gallic acid and quercetin equivalents, respectively (GAE and QE), per gram of dry extract.

Table 4. ABTS and DPPH free radical activity of honey extracts examined in the present study.

\begin{tabular}{ccc}
\hline Honey Extract & $\begin{array}{c}\text { ABTS Inhibition (\%) } \\
\mathbf{C}=\mathbf{1 6 . 6 7} \mathbf{~ m g} / \mathbf{m L}\end{array}$ & $\begin{array}{c}\text { DPPH Inhibition (\%) } \\
\mathbf{C}=\mathbf{0 . 2 5} \mathbf{~ m g} / \mathbf{m L}\end{array}$ \\
\hline ME1.3 & $22.90 \pm 1.32$ & $55.50 \pm 2.33$ \\
ME5.3 & $23.95 \pm 2.28$ & $56.10 \pm 1.25$ \\
ME11.2 & $22.80 \pm 3.29$ & $67.00 \pm 4.88$ \\
ME16.1 & $18.20 \pm 4.55$ & $51.00 \pm 5.20$ \\
ME20.3 & $25.80 \pm 3.22$ & $61.00 \pm 3.89$ \\
\hline \multicolumn{3}{c}{ (C: Concentration). }
\end{tabular}

The extracts displayed similar antioxidant profiles based on the ABTS and DDPH assay, and we continued our study with the honey extracts ME16.1 and ME20.3 as these became the first available at sufficient quantities. The cytotoxicity of the extracts were tested in HaCaT cells line using the SRB assay. Cells were treated with increasing concentrations (0-200 $\mu \mathrm{g} / \mathrm{mL})$ of ME16.1 or ME20.3 extracts for $24 \mathrm{~h}$, and cell viability was evaluated as percent of control (untreated cells) viability (Figure 1). The efficient concentrations of the extracts leading to a $50 \%$ and $10 \%$ decrease in cell viability $\left(\mathrm{EC}_{50}\right.$ and $\mathrm{EC}_{10}$, respectively) were also calculated (Table 5). As illustrated in Figure 1, the honey

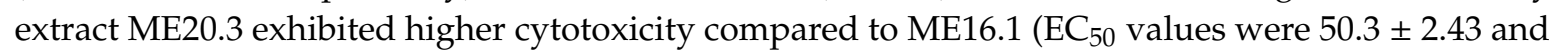
$91.03 \pm 4.23 \mu \mathrm{g} / \mathrm{mL}$, respectively). However, their $\mathrm{EC}_{10}$ values were similar, being $27.14 \pm 1.41 \mu \mathrm{g} / \mathrm{mL}$ and $28.87 \pm 0.54 \mu \mathrm{g} / \mathrm{mL}$ for ME20.3 and ME16.1, respectively (Table 5). Based on the observation that $20 \mu \mathrm{g} / \mathrm{mL}$ of each extract induced $<10 \%$ reduction in cell viability, this concentration was further chosen for all subsequent experiments. To assess whether these honey extracts possess UV-screening properties, we analysed the absorption spectrum of the samples ME16.1 and ME20.3. Based on the absorbance spectra, both extracts demonstrated absorption in the UV region (Tables S1 and S2, Figure S1) suggesting a potential photoprotective role.

Table 5. The $\mathrm{EC}_{50}$ and $\mathrm{EC}_{10}$ value of honey extracts ME20.3 and ME16.1.

\begin{tabular}{ccc}
\hline Honey Extract & EC $_{\mathbf{5 0}}(\mu \mathrm{g} / \mathbf{m L})^{\mathbf{1}}$ & EC $_{\mathbf{1 0}}(\mu \mathrm{g} / \mathrm{mL})^{\mathbf{1}}$ \\
\hline ME16.1 & $91.03 \pm 4.23$ & $28.87 \pm 1.41$ \\
ME20.3 & $50.3 \pm 2.43$ & $27.14 \pm 0.54$ \\
\hline
\end{tabular}

${ }^{1}$ Results are presented as the mean \pm SD of three independent experiments. 


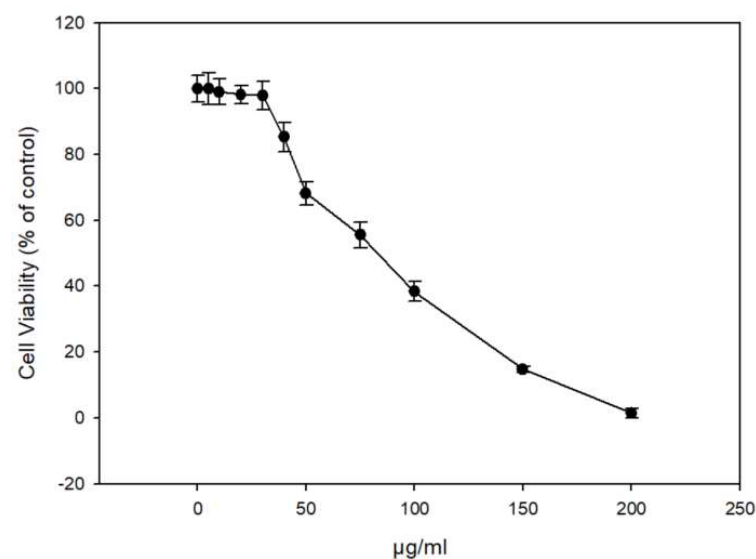

(a)

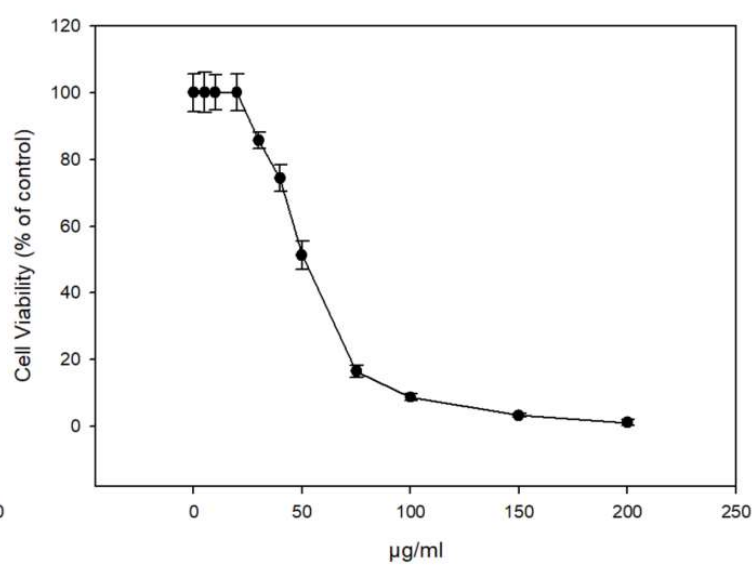

(b)

Figure 1. In vitro cytotoxicity assessment of honey extracts in human immortalized epidermal keratinocytes (HaCaT) cells. HaCaT cells were incubated with increasing concentrations of ME16.1 (a) and ME20.3 (b) honey extracts $(0-200 \mu \mathrm{g} / \mathrm{mL})$ for $24 \mathrm{~h}$. Cell viability was determined by the SRB assay as described in Materials and Methods. The results are shown as \pm SD of three independent experiments.

\subsection{Honey Extracts Protect HaCaT Cells against UVB-Induced DNA Damage}

To evaluate the antimutagenic activity of the ME16.1 and ME20.3 honey extracts, we employed the single cell gel electrophoresis assay (comet assay) in order to evaluate the UVB-induced DNA damage in $\mathrm{HaCaT}$ cells in their presence or absence. To this end, $\mathrm{HaCaT}$ cells were pre-incubated with $20 \mu \mathrm{g} / \mathrm{mL}$ of honey extracts and then were UVB-irradiated $\left(0.2 \mathrm{~min}, 55 \mathrm{~mJ} / \mathrm{cm}^{2}\right)$. Following irradiation, cells were further incubated with $20 \mu \mathrm{g} / \mathrm{mL}$ of ME16.1 (Figure 2a) or ME20.3 (Figure 2b) extract for another $2 \mathrm{~h}$ and left to recover for $24 \mathrm{~h}$. The comet assay was performed under alkaline conditions to detect both single and double strand DNA breakage. As shown in Figure 2, exposure of HaCaT cells to UVB radiation strongly increased the levels of DNA damage, whereas treatment of HaCaT cells only with the honey extracts had no mutagenic effect. ME16.1 appeared to significantly reduce basal DNA damage levels, but not ME20.3. Importantly, treatment with honey extracts exhibited considerable antimutagenic activity and significantly decreased UVB-induced DNA damage (Figure 2a,b, respectively).

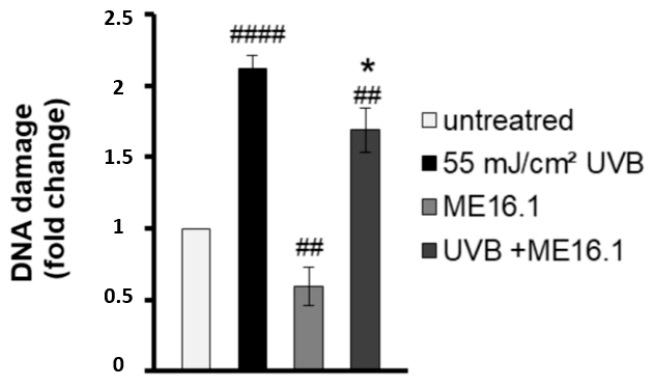

(a)

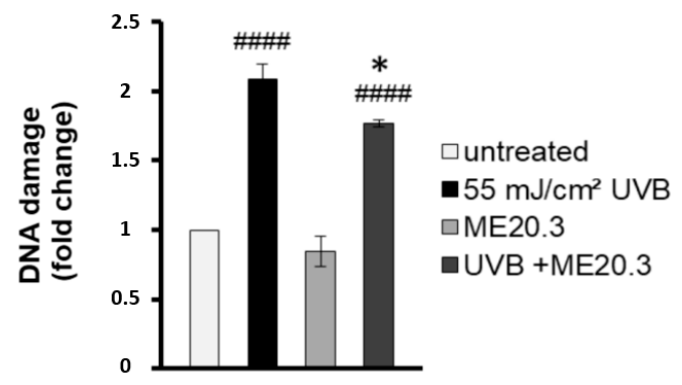

(b)

Figure 2. Honey extracts protect HaCaT cells from UVB-induced DNA damage. Cells were pre-incubated with $20 \mu \mathrm{g} / \mathrm{mL}$ of ME16.1 (a) or ME20.3 (b) for $2 \mathrm{~h}$ and then were either UVB-irradiated $\left(55 \mathrm{~mJ} / \mathrm{cm}^{2}\right.$; treated) or left untreated (control). Treated and control cells were further incubated for $2 \mathrm{~h}$ in the presence or absence of honey extracts, left to recover for $24 \mathrm{~h}$ and then subjected to single cell gel electrophoresis (comet) assay. Data represent the fold-change of DNA damage in untreated (white), UVB-irradiated (black), honey-treated (light grey) and UVB-irradiated/honey-treated cells (dark grey). Data presented are the mean $\pm \mathrm{SD}$ of three independent experiments performed in duplicates. $\# \# p \leq 0.01$, \#\#\# $p \leq 0.001$, significant differences compared to untreated cells $* p \leq 0.05$, significant differences between UVB-irradiated and honey-treated/UVB-irradiated cells. 


\subsection{Honey Extracts Protect HaCaT Cells against UVB-Induced Cytotoxicity and Protein Oxidation}

Next, we investigated the potentially protective effects of the honey extracts against UVB-induced cytotoxicity in $\mathrm{HaCaT}$ cells, through phase contrast microscopy and trypan blue exclusion assay. As shown in Figure 3, UVB exposure triggered a significant decrease in cell viability $(>60 \%)$, whereas treatment of $\mathrm{HaCaT}$ cells with ME16.1 and ME20.3 honey extracts significantly inhibited UVB-induced cytotoxicity (Figure 3). In the case of treatment with the ME16.1, $62.3 \pm 6.44 \%$ cell viability was observed, while for ME20.3, 73.23 $\pm 4.23 \%$ cell viability was also observed under conditions of UVB irradiation (Figure 3a). The morphological appearance of $\mathrm{HaCaT}$ cells as observed by phase-contrast microscopy under all experimental conditions is illustrated in Figure $3 \mathrm{~b}$.

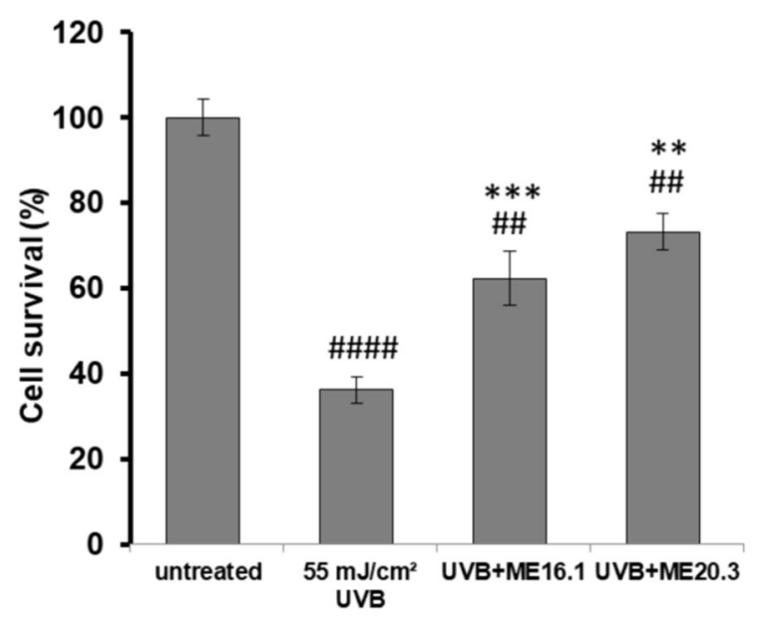

(a)
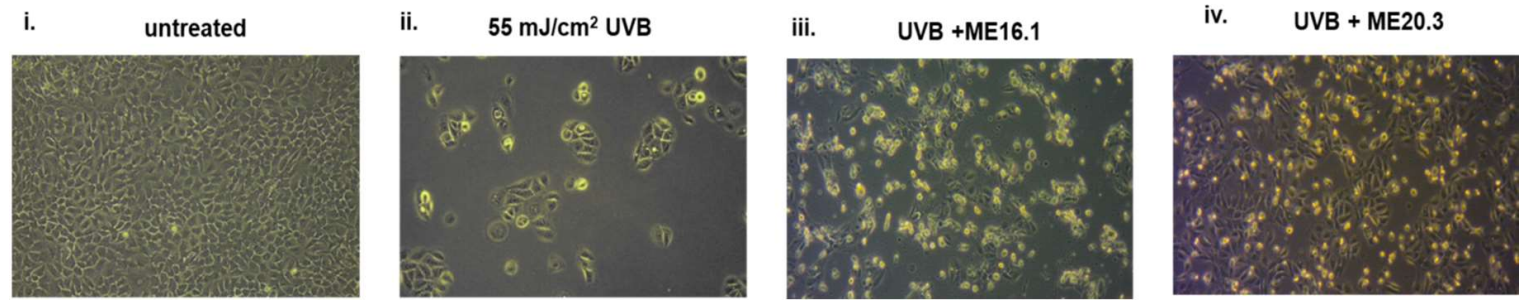

(b)

Figure 3. Protection of $\mathrm{HaCaT}$ cells by honey extracts against UVB-induced cytotoxicity. Cells were pre-incubated with $20 \mu \mathrm{g} / \mathrm{mL}$ of honey extracts for $2 \mathrm{~h}$, and then were UVB-irradiated $\left(55 \mathrm{~mJ} / \mathrm{cm}^{2}\right)$ followed by further incubation for $2 \mathrm{~h}$. Following a $24 \mathrm{~h}$ recovery period, cell viability was examined by trypan blue exclusion assay and phase contrast microscopy. (a) Cell viability determined by the trypan blue exclusion assay. Data presented are the mean \pm SD of three independent experiments performed in duplicates. \#\# $p \leq 0.01$, \#\#\#\# $p \leq 0.001$, significant differences compared to untreated cells, ${ }^{* *} p \leq 0.01$, *** $p \leq 0.001$, significant differences between UVB-irradiated and honey-treated/UVB-irradiated cells. (b) Phase contrast microscopy of non-irradiated (i), UVB-irradiated (ii) and UVB-irradiated cells treated with ME16.1 (iii) and ME20.3 (iv). Representative figures of ten random fields for each condition examined in triplicates. 
In line with the above, we examined whether the protective effects of honey extracts against UVB-induced cytotoxicity were attributed to their antioxidant properties. Therefore, HaCaT cells were pre-incubated with each of the honey extracts for $2 \mathrm{~h}$, exposed to UVB radiation and then incubated again with each honey extract for further $2 \mathrm{~h}$. Cell lysates were subjected to Trolox antioxidant capacity and DNPH protein carbonyl assays. Overall, differences in total antioxidant content and activity between untreated and UVB-irradiated cells (treated with or without the honey extracts) were not significantly different (Figure 4a). On the other hand, UVB irradiation increased the protein carbonyl levels and triggered protein oxidation in HaCaT cells. Remarkably, treatment of the UVB-irradiated $\mathrm{HaCaT}$ cells with the honey extracts ME16.1 or ME20.3 substantially decreased the total protein carbonyl levels and thus inhibited protein oxidation (Figure $4 b$ ).

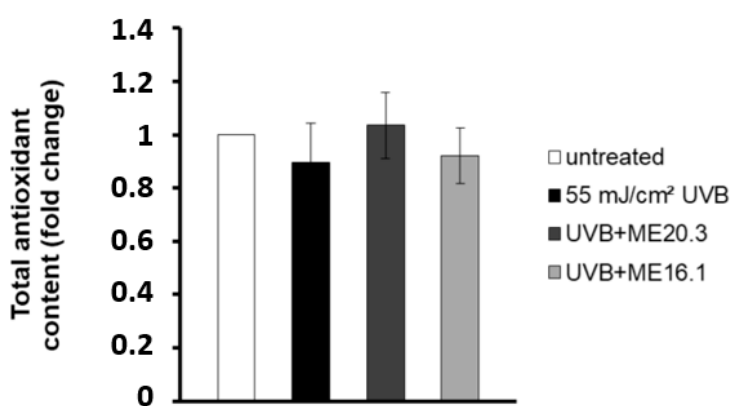

(a)

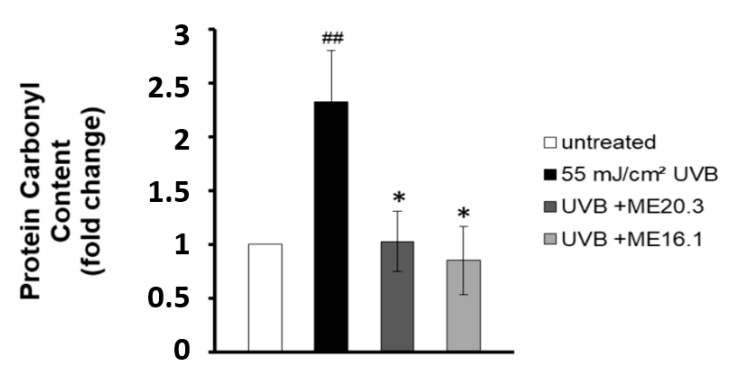

(b)

Figure 4. Honey extracts protect HaCaT cells from UVB-induced protein oxidation. HaCaT cells were pre-incubated with $20 \mu \mathrm{g} / \mathrm{mL}$ of honey extracts and then were either exposed to UVB irradiation $\left(55 \mathrm{~mJ} / \mathrm{cm}^{2}\right)$ or left untreated. Cells were treated for $2 \mathrm{~h}$ with honey extracts and then allowed to recover for $24 \mathrm{~h}$. (a) Total antioxidant content and activity in HaCaT cell lysates was assessed by the ABTS oxidation assay and expressed as fold change in Trolox equivalents compared to untreated cells. (b) Protein oxidation was estimated by measuring the protein carbonyl levels with the DNPH colorimetric assay. The concentration of the protein carbonyls was determined and adjusted to the total protein concentration (expressed as fold-change compared to the untreated cells). Data shown are the mean $\pm \mathrm{SD}$ of three independent experiments performed in triplicates. \#\# $p \leq 0.01$, significant differences compared to untreated cells, ${ }^{*} p \leq 0.05$, significant differences between UVB-irradiated and honey-treated/UVB-irradiated cells.

\subsection{Honey Extracts Inhibit UVB-Induced Over-Expression of Matrix Metalloproteinases (MMPs) in a Human Reconstituted Skin Model}

We further evaluated the protective effects of honey extracts ME16.1 and ME20.3 against UVB-induced photo-aging in the human reconstituted skin model Epiderm ${ }^{\mathrm{TM}}$ EPI-200, which simulates human skin. The upper surface of the reconstituted skin tissues was incubated with ME16.1 or ME20.3 for $2 \mathrm{~h}$ and then exposed to UVB irradiation $\left(55 \mathrm{~mJ} / \mathrm{cm}^{2}\right)$. It was then further treated with the honey extracts for an additional $2 \mathrm{~h}$. The medium was changed and then, following 24-h incubation, tissues were harvested and H\&E stained in order to observe any UVB-induced skin lesions (Figure 5). Representative pictures of untreated tissues are shown in Figure 5a. UVB irradiation caused severe damage with total necrosis of keratinocytes (Figure 5b). On the contrary, pre-treatment of the UVB-irradiated skin tissues with the ME16.1 resulted in a moderate damage, including a decrease in keratinosomes intercellular oedema and rare sunburn cells (Figure 5c). Similarly, treatment with the ME20.3 extract resulted in moderate damage, including intercellular oedema and few sunburn cells (pyknotic nuclei) in the stratum granulosum layer (Figure 5d). 


\section{untreated}

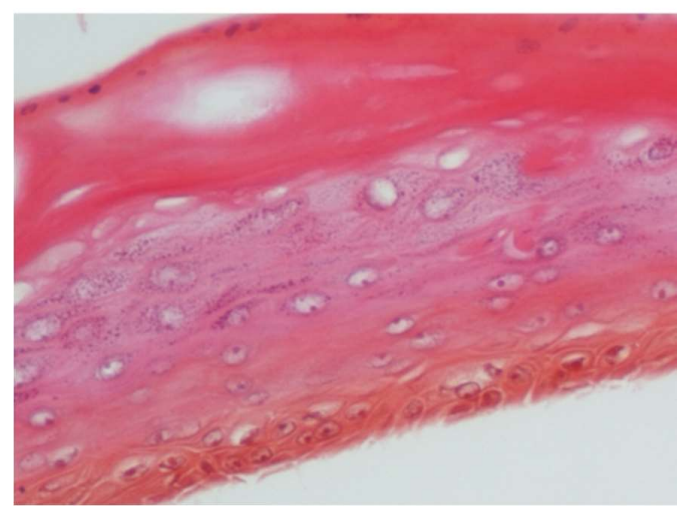

(a)

\section{UVB + ME16.1}

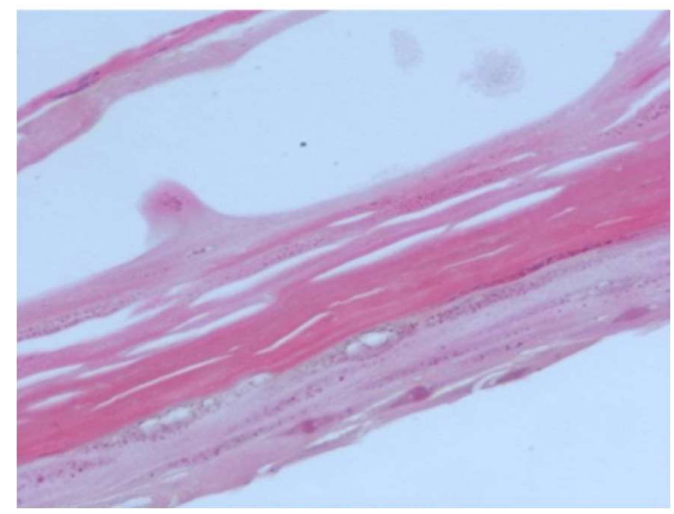

(c)
$55 \mathrm{~mJ} / \mathrm{cm}^{2}$ UVB

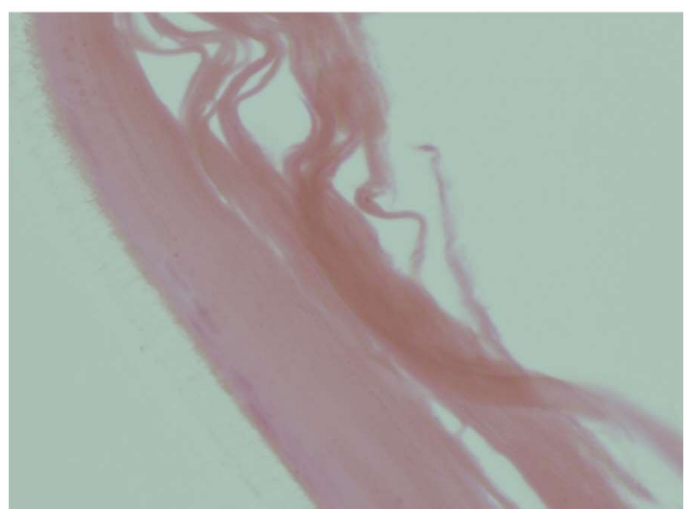

(b)

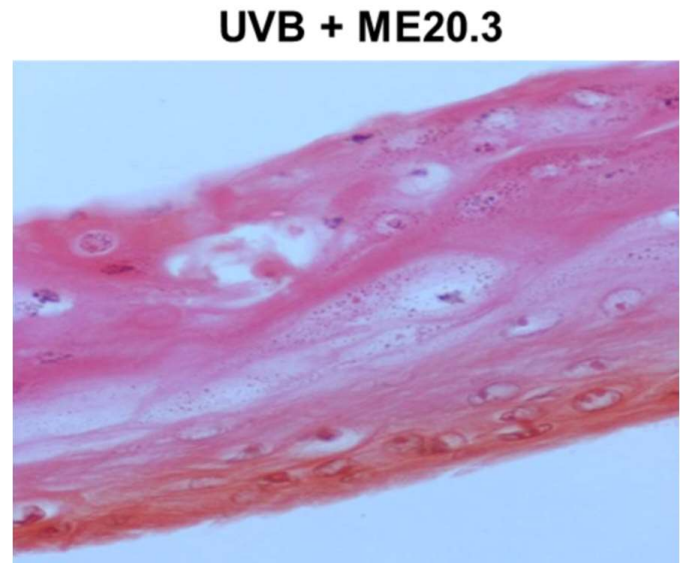

(d)

Figure 5. Assessment of the protective effect of honey extracts against UVB-induced skin damage. Epiderm $^{\mathrm{TM}}$ EPI-200 reconstituted skin tissues were treated in the apical surface with $20 \mu \mathrm{g} / \mathrm{mL}$ of honey extracts (diluted in assay culture medium) for $2 \mathrm{~h}$, washed with PBS and then exposed to $55 \mathrm{~mJ} / \mathrm{cm}^{2}$ of UVB irradiation. After UVB exposure, the tissues were incubated with honey extracts for $2 \mathrm{~h}$ and then washed with $1 \times$ PBS. After $24 \mathrm{~h}$, the tissues were harvested and sections were taken. Representative images of H\&E staining of untreated (a), UVB-irradiated (b), and pre-treated with ME16.1 (c), or ME20.3 (d) skin tissues. Magnification $\times 400$.

Moreover, the expression levels of $M M P s$ were estimated by quantitative PCR in skin tissues that had been exposed to UVB and treated with or without pre-treatment with ME16.1 or ME20.3. As shown in Figure 6, UVB irradiation of the reconstituted skin tissues resulted in significant over-expression of all MMPs examined. Pre-treatment with ME16.1 caused a significant decrease in the UVB-induced upregulation of MMPs-3, -7, and -9 mRNA levels (Figure 6a). Similar results were documented for the ME20.3 (Figure 6b). Finally, although UVB irradiation did not induce MMP-1 gene expression levels, significant up-regulation of $M M P-1$ was observed in the presence of both honey extracts, being more prominent in the case of the ME20.3. 


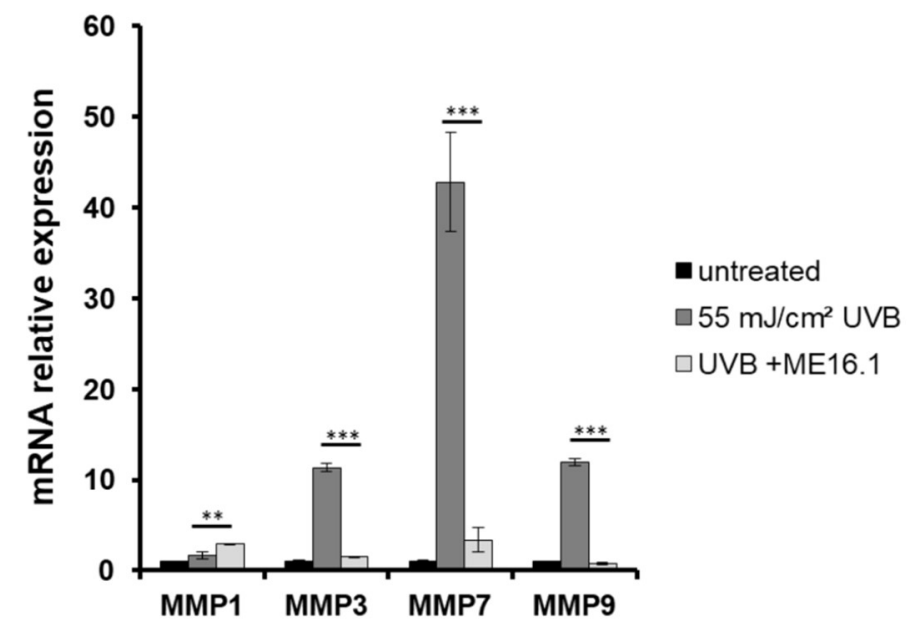

(a)

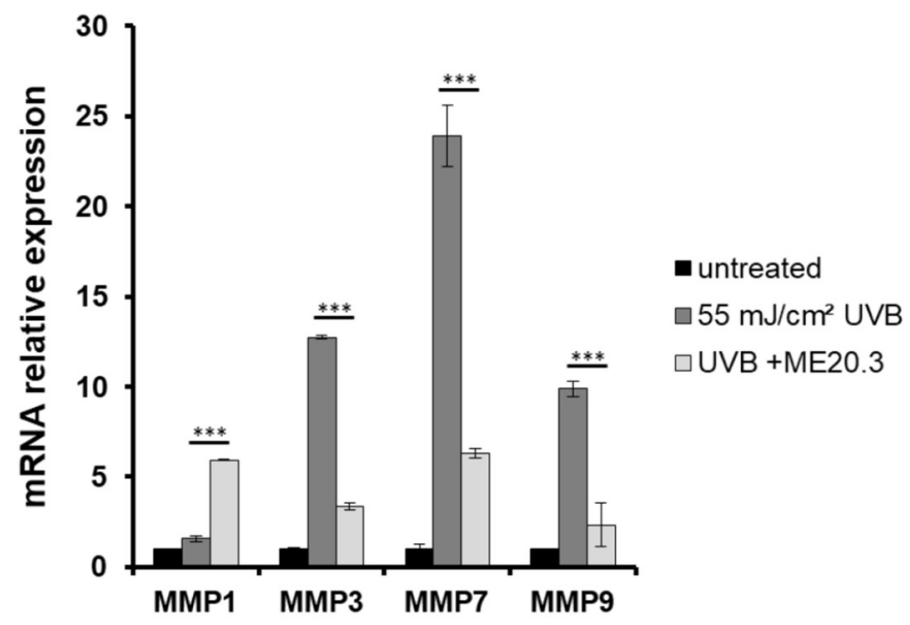

(b)

Figure 6. Honey extracts modulate the UVB-induced mRNA expression of MMPs in a 3D reconstituted human skin model (Epiderm ${ }^{\mathrm{TM}}$ EPI-200). Tissues were pre-treated with $20 \mu \mathrm{g} / \mathrm{mL}$ of honey extracts ME16.1 (a) or ME20.3 (b) for $2 \mathrm{~h}$, UVB irradiated $\left(55 \mathrm{~mJ} / \mathrm{cm}^{2}\right)$ and then treated with honey extracts for $2 \mathrm{~h}$. After $24 \mathrm{~h}$, the tissues were harvested and total RNA was extracted. For the quantification of MMPs-1, -3, -7 and -9 mRNA levels quantitative real-time PCR was performed. The expression levels of all MMPS were normalized to those of $\beta$-actin. Untreated cells served as reference sample. For the relative quantification, the formula $R Q=2^{-\Delta \Delta C t}$ was used. Representative graphs of three independent experiments. Each reaction was performed in triplicate. ${ }^{* *} p \leq 0.01,{ }^{* * *} p \leq 0.001$, significant differences compared to the UVB-irradiated cells.

To further evaluate the protective effects of honey extracts against the UVB-induced up-regulation of MMPs at the protein level, immunohistochemical analysis was performed. As shown in Figure 7, UVB exposure resulted in over-expression of all the MMPs, and especially those of MMP-3 and MMP-9 (Figure 7B,F,J,N). Treatment with ME20.3 resulted in a significant decrease in the protein levels of all MMPs tested (Figure 7D,H,L,P), compared to UVB-irradiated skin tissues. Similarly, treatment with ME16.1 also decreased the protein expression levels of all MMPs tested (Figure 7C,G,K,O), but to a lesser extent than ME20.3. 

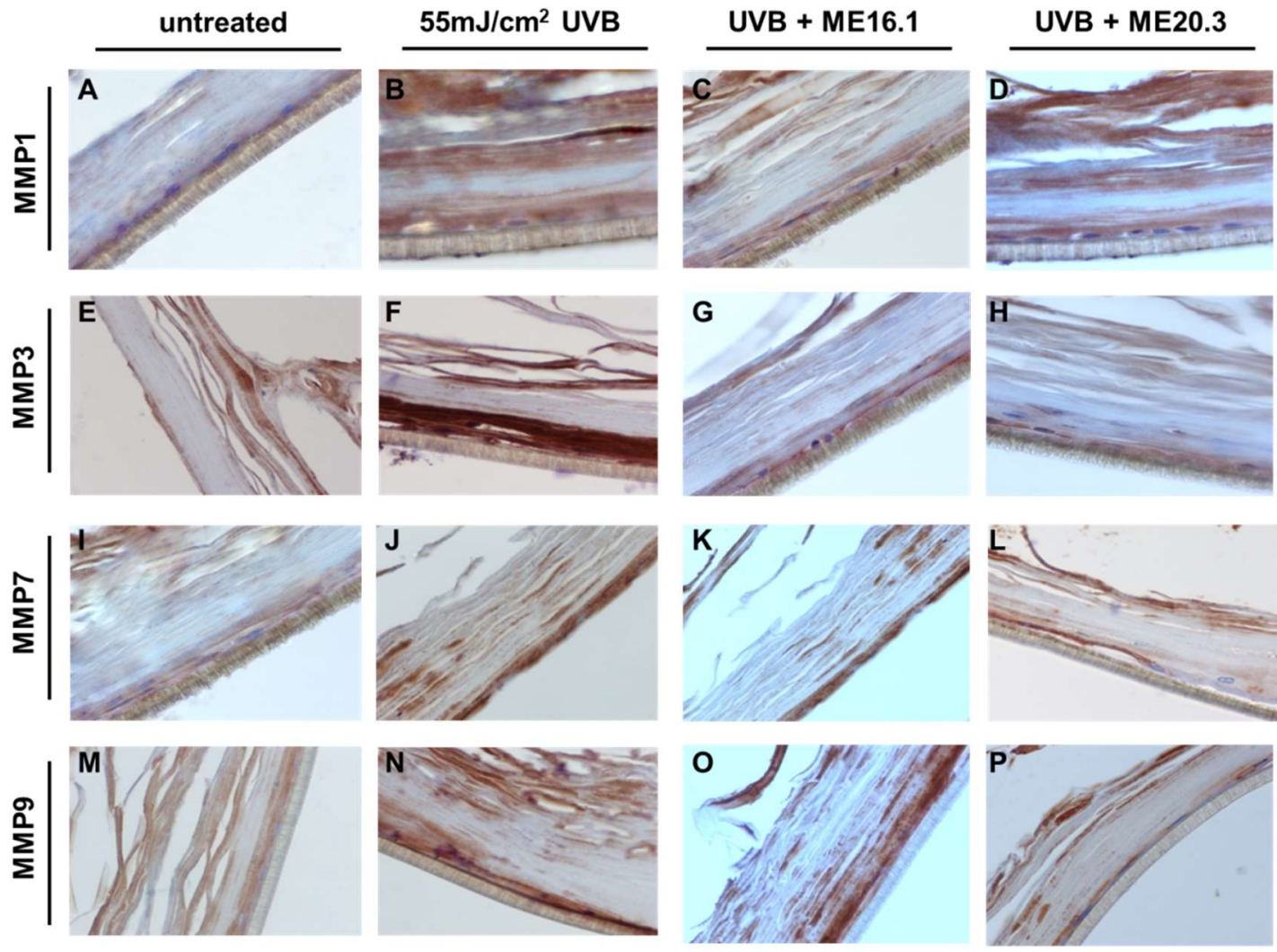

Figure 7. Honey extracts inhibit the UVB-induced expression of MMPs in a 3D reconstituted human skin model (Epiderm ${ }^{\mathrm{TM}}$ EPI-200). Tissues were pre-treated with $20 \mu \mathrm{g} / \mathrm{mL}$ of honey extracts ME16.1 or ME20.3 for $2 \mathrm{~h}$, followed by UVB irradiation $\left(55 \mathrm{~mJ} / \mathrm{cm}^{2}\right)$ and then incubation with honey extracts for $2 \mathrm{~h}$. After $24 \mathrm{~h}$, the tissues were harvested, sections were taken and immunostaining was performed to detect UVB-induced MMP-1 (A-D), MMP-3 (E-H), MMP-7 (I-L) and MMP-9 (M-P) positive cells. Representative images at 400× magnification of untreated (A,E,I,M), UVB-irradiated (B,F,J,N), ME16.1 pre-treated/UVB-irradiated $(\mathbf{C}, \mathbf{G}, \mathbf{K}, \mathbf{O})$ and ME20.3 pre-treated/UVB-irradiated $(\mathbf{D}, \mathbf{H}, \mathbf{L}, \mathbf{P})$ tissues.

\section{Discussion}

Long-term exposure to solar UV radiation causes the accumulation of skin photodamage, resulting in a wide spectrum of skin pathologies, such as inflammation, atrophy, delayed wound healing, carcinogenesis and photoaging $[35,47]$. The latter is mediated by UV radiation (UVR) through various modes of action, such as the formation of reactive oxygen species (ROS), the induction of DNA damage, the up-regulation of specific MMPs and the inhibition of collagen bio-synthesis [48,49]. Therefore, effective antiaging cosmeceutical agents should ideally possess antioxidant, antimutagenic and antiaging properties. To this end, honey is a natural bee-derived product, widely known for its medicinal and health promoting properties [16]. While, a great number of studies have been focused on its antibacterial, antiviral, anticancer antiproliferative, anti-inflammatory and wound healing capacities $[21,27,28,50]$, its potential as an antiaging agent has not been yet clarified. Therefore, we were prompted to investigate its antioxidant, antimutagenic and antiaging properties under experimental conditions of UVB exposure.

In our study, honey samples were collected from various botanical origins and geographical regions of Greece and extracts were produced. The total phenolic and flavonoid content as well as their in vitro antioxidant activity were initially determined. Two selected samples were further processed and characterized for their antioxidant and photoprotective properties under UVB exposure conditions. Our results indicated that the honey extracts exhibited strong antioxidant and antimutagenic capacity and protected $\mathrm{HaCaT}$ cells against the cytotoxic and oxidative effects of UVB irradiation. Furthermore, 
honey extracts protected against UVB-induced severe photodamage and sufficiently attenuated the UVB-induced MMP up-regulation using a reconstituted human skin tissue model.

The in vitro antioxidant capacity of the extracts was initially studied by employing cell-free well-established methodologies, such as ABTS and DPPH assays. Our results showed that all honey extracts exhibited significant antioxidant activity that may be related with their phenolic and flavonoid content. This finding is in accordance with previous studies demonstrating the antioxidant properties of honey extracts [51-57]. Interestingly, a strong correlation between the TPC and the antioxidant capacity of honey has been reported by a great number of studies [58-60]. However, in our study, all samples, exhibited relatively similar antioxidant capacity, ranging from $18.2 \%$ to $25.8 \%$ and $51 \%$ to $67 \%$ inhibition for ABTS and DPPH, respectively. A significant correlation was found between the TPC of the extracts and the ABTS free radical activity (Pearson correlation of 0.61705). On the contrary, no significant correlation was monitored between the TFC and the antioxidant capacity of the extracts, probably because of their low concentration. Quite interestingly, the ME16.1 and ME20.3 extracts demonstrated significant antioxidant activity in HaCaT cells under UVB exposure conditions. Although monitoring the total cellular antioxidant activity did not prove as sensitive and did not reveal any differences between experimental conditions in the absence or presence of the honey extracts, monitoring the cellular protein oxidation levels indicated significant differences. UVB irradiation increased the protein carbonyl levels and triggered protein oxidation in $\mathrm{HaCaT}$ cells, and treatment with the honey extracts ME16.1 or ME20.3 substantially alleviated these effects, suggesting strong antioxidant activity of the honey extracts.

The main class of polyphenols in honey are flavonoids and phenolic acids. Flavonoids are mostly recognized as aglycones and not in their glycosylated forms largely due to the presence of glucosidase activity in the salivary glands of bees responsible for the hydrolysis of flavonoid glycosides and the release of the aglycon forms. Phenolic aglycons are more readily absorbed by the gut barrier by passive diffusion and therefore have increased bioavailability [61]. The bioactive flavonoid and phenolic compounds found in different honey types have been recently reviewed [62]. It appears that individual bioactive compounds are similar across different types of honey, but vary in their relative concentrations. Several studies have evaluated the antioxidant properties of honey in vitro and in vivo. The specific honey variety manuka, via its bioactive compounds such as methylglyoxal, decreased intracellular ROS levels, protein and lipid oxidation damage and apoptosis and improved mitochondrial functionality and antioxidant enzyme activities by activating the AMPK-Nrf2 pathway in human dermal fibroblasts [63]. Improved antioxidant status was observed in HepG2 cells treated with bee honey, while an increase in antioxidant enzyme expression and activities has been proved in human diploid fibroblasts treated with monofloral gelam honey [64]. Different types of honey have proved to prevent oxidative damage by reducing ROS levels, inhibiting lipid peroxidation and DNA damage levels and increasing antioxidant enzyme activities in several in vivo models [65-68].

In our study the honey extracts ME16.1 and ME20.3 effectively protected cells from UVB-induced DNA damage. Our results are consistent with previous findings demonstrating an antimutagenic effect of honey against various genotoxic agents (e.g., $\mathrm{UV}, \mathrm{H}_{2} \mathrm{O}_{2}$, pesticides) [69-73]. For instance, Ahmad et al. reported that treatment with tualang honey significantly inhibited UVB-induced formation of CPD and 8-oxodG DNA adducts in the murine epidermal keratinocyte cell line PAM212 [73]. Similarly, Cheng et al. showed that treatment with whole honey resulted in reduced $\mathrm{H}_{2} \mathrm{O}_{2}$-induced DNA damage in mice lymphocytes [69]. In an experimental model of human hepatoma (HepG2) cells, honey samples of different floral origin protected against DNA strand breaks induced by several dietary mutagens, such as benzo(a)pyrene (BaP), 2-amino-1-methyl-6-phenylimidazol (4, 5-b)pyridine (PhIP), $\mathrm{N}$-nitrosopyrrolidine (NPYR), but not N-nitrosodimethylalmine (NMDA). This protective effect was in part attributed to the phenolic content of the honey samples [74]. The post-treatment of human whole blood samples from healthy volunteers with manuka honey resulted in significant protection of whole blood cells from oxidative damage induced by hydrogen peroxide monitored in vitro by comet 
assay [75]. To the extent of our knowledge, this is the first time that the protective effect of honey against UV genotoxicity has been demonstrated in human keratinocytes.

Additionally, the honey extracts protected $\mathrm{HaCaT}$ cells against the cytotoxic, oxidative, and photodamaging effects of UVB. The treatment of HaCaT cells with the honey extracts attenuated the decrease in cell viability following UVB exposure and significantly decreased the oxidative protein damage within the cells, as indicated by decreased total protein carbonyl content following UVB irradiation. The Epiderm ${ }^{\mathrm{TM}}$ EPI-200 reconstituted human skin model was utilized to further confirm the photoprotective properties of honey extracts against UVB irradiation. One of the various mechanisms through which UV radiation is related with photoaging is through matrix metalloproteinases (MMPs) up-regulation. MMPs induce alterations of the extracellular matrix (ECM) by degrading proteoglycan, elastin, fibronectin, and collagen, leading to wrinkle formation [76]. Interestingly, the examined honey extracts suppressed the UVB-induced up-regulation of MMPs $-3,-7$ and -9 both at mRNA and protein level in the reconstituted human skin model. Intriguingly, UVB radiation could marginally induce the expression of $M M P 1$ at mRNA level, while treatment with the honey extracts could further augment the expression of MMP1. However, this increase was not recapitulated at protein level, as shown by IHC. The same model has been previously used to study the cytoprotective properties of propolis extracts against photodamage [40]. Only a few other reports have investigated the antioxidant, cytoprotective and antiaging effect of honey in skin after UV radiation exposure. For instance, similarly with our data, Majtan et al. demonstrated that honey extracts substantially inhibited the TNF- $\alpha$-induced up-regulation of MMP-9 in HaCaT cells in a dose-dependent manner [77]. Similarly, Moskwa et al. reported that treatment with honey samples of Polish origin significantly down-regulated MMP-2 and MMP-9 in the human glioblastoma U87MG cell line [78].

To summarize, the results of the present study demonstrate that the tested honey extracts confers protection against UVB-induced skin cellular damage by attenuating UVB-induced toxicity, reducing the cellular and DNA damage levels and modulating the expression levels of several MMPs. These findings suggest that honey could be considered a promising agent for the development of naturally based cosmetic products. Future studies are required to shed more light into elucidating the molecular mechanism(s) underlying the cytoprotective properties of honey under UV exposure conditions as well as to characterize its active components responsible for such specific mode(s) of action.

Supplementary Materials: The following are available online at http://www.mdpi.com/2076-3921/9/7/566/s1, Figure S1: Absorption spectrum (190-800 nm) of honey extracts (ME16.1 and ME20.3) at $20 \mu \mathrm{g} / \mathrm{mL}$, Table S1: Absorption spectrum of ME16.1 sample in different concentrations $(\mu \mathrm{g} / \mathrm{mL})$, Table S2: Absorption spectrum of ME20.3 sample in different concentrations $(\mu \mathrm{g} / \mathrm{mL})$.

Author Contributions: Conceptualization, N.A., K.G., M.I.P., and A.P.; methodology, N.A., A.G., M.L., M.I.P., and A.P.; validation, A.K., G.-P.V., I.T.; formal analysis, A.K., G.-P.V., M.L., N.A. and A.P.; investigation, N.A., K.G., M.I.P., and A.P.; resources N.A., M.L., K.G., M.I.P. and A.P.; data curation, A.K., G.-P.V., D.I., P.M., I.T., K.S., M.-I.S., S.K. (Spyridon Kynigopoulos), S.K. (Sofia Karabournioti); writing一original draft preparation, A.K., G.-P.V., I.T. and K.S.; writing-review and editing, N.A., M.L., K.G., A.G., M.I.P.; A.P.; visualization, A.K., G.-P.V., I.T.; supervision, N.A., M.L., A.G., and A.P.; project administration, K.G., A.G., and A.P.; funding acquisition, N.A., K.G., M.I.P. and A.P. All authors have read and agreed to the published version of the manuscript.

Funding: The present study was supported by a "Greece-China Bilateral R\&D Cooperation 2013-2015" NSFR grant (Project Nr. 12CHN167).

Conflicts of Interest: The authors declare no conflict of interest.

\section{References}

1. Farley, A.; McLafferty, E.; Hendry, C. The anatomy and physiology of the locomotor system. Nurs. Stand. 2012, 27, 35-43. [CrossRef] [PubMed]

2. Kanitakis, J. Anatomy, histology and immunohistochemistry of normal human skin. Eur. J. Dermatol. 2002, 12, 390-401. [PubMed]

3. Gallo, R.L. Human Skin Is the Largest Epithelial Surface for Interaction with Microbes. J. Investig. Dermatol. 2017, 137, 1213-1214. [CrossRef] 
4. Matsumura, Y.; Ananthaswamy, H.N. Toxic effects of ultraviolet radiation on the skin. Toxicol. Appl. Pharmacol. 2004, 195, 298-308. [CrossRef] [PubMed]

5. Diffey, B.L. Sources and measurement of ultraviolet radiation. Methods 2002, 28, 4-13. [CrossRef]

6. Gilchrest, B.A. A review of skin ageing and its medical therapy. Br. J. Dermatol. 1996, 135, 867-875. [CrossRef]

7. Narayanan, D.L.; Saladi, R.N.; Fox, J.L. Ultraviolet radiation and skin cancer. Int. J. Dermatol. 2010, 49, 978-986. [CrossRef]

8. McCallion, R.; Po, A.L.W. Dry and photo-aged skin:and manifestations management. J. Clin. Pharm. Ther. 1993, 18, 15-32. [CrossRef]

9. Chen, H.; Weng, Q.Y.; Fisher, D.E. UV signaling pathways within the skin. J. Investig. Dermatol. 2014, 134, 2080-2085. [CrossRef]

10. Park, J.M.; Kang, T.H. Transcriptional and posttranslational regulation of nucleotide excision repair: The guardian of the genome against ultraviolet radiation. Int. J. Mol. Sci. 2016, 17, 1840. [CrossRef]

11. Xuan, S.H.; Park, Y.M.; Ha, J.H.; Jeong, Y.J.; Park, S.N. The effect of dehydroglyasperin C on UVB-mediated MMPs expression in human HaCaT cells. Pharmacol. Rep. 2017, 69, 1224-1231. [CrossRef] [PubMed]

12. Verma, R.P.; Hansch, C. Matrix metalloproteinases (MMPs): Chemical-biological functions and (Q)SARs. Bioorganic Med. Chem. 2007, 15, 2223-2268. [CrossRef] [PubMed]

13. Rinnerthaler, M.; Bischof, J.; Streubel, M.K.; Trost, A.; Richter, K. Oxidative stress in aging human skin. Biomolecules 2015, 5, 545-589. [CrossRef]

14. Sharma, P.; Jha, A.B.; Dubey, R.S.; Pessarakli, M. Reactive Oxygen Species, Oxidative Damage, and Antioxidative Defense Mechanism in Plants under Stressful Conditions. J. Bot. 2012, 2012, 1-26. [CrossRef]

15. Siddiqui, A.J.; Musharraf, S.G.; Choudhary, M.I.; Rahman, A.U. Application of analytical methods in authentication and adulteration of honey. Food Chem. 2017, 217, 687-698. [CrossRef] [PubMed]

16. Premratanachai, P.; Chanchao, C. Review of the anticancer activities of bee products. Asian Pac. J. Trop. Biomed. 2014, 4, 337-344. [CrossRef] [PubMed]

17. Pichichero, E.; Canuti, L.; Canini, A. Characterization of the phenolic and flavonoid fractions and antioxidant power of Italian honeys of different botanical origin. J. Sci. Food Agric. 2009, 89, 609-616. [CrossRef]

18. Rahman, M.M.; Gan, S.H.; Khalil, M.I. Neurological effects of honey: Current and future prospects. Evid. Based Complement. Altern. Med. 2014, 2014, 958721. [CrossRef]

19. Cooper, R. Honey for wound care in the 21st century. J. Wound Care 2016, 25, 544-552. [CrossRef]

20. Molan, P.C.; Betts, J.A. Clinical usage of honey as a wound dressing: An update. J. Wound Care 2004, 13, 353-356. [CrossRef]

21. Israili, Z.H. Antimicrobial properties of honey. Am. J. Ther. 2014, 21, 304-323. [CrossRef] [PubMed]

22. Erejuwa, O.O.; Sulaiman, S.A.; Wahab, M.S. Effects of honey and its mechanisms of action on the development and progression of cancer. Molecules 2014, 19, 2497-2522. [CrossRef]

23. Erejuwa, O.O.; Sulaiman, S.A.; Wahab, M.S. Honey: A novel antioxidant. Molecules 2012, 17, 4400-4423. [CrossRef] [PubMed]

24. Viuda-Martos, M.; Ruiz-Navajas, Y.; Fernández-López, J.; Pérez-Álvarez, J.A. Functional properties of honey, propolis, and royal jelly. J. Food Sci. 2008, 73, R117-R124. [CrossRef] [PubMed]

25. Mandal, M.D.; Mandal, S. Honey: Its medicinal property and antibacterial activity. Asian Pac. J. Trop. Biomed. 2011, 1, 154-160. [CrossRef]

26. Kasala, E.R.; Bodduluru, L.N.; Madana, R.M.; Athira, K.V.; Gogoi, R.; Barua, C.C. Chemopreventive and therapeutic potential of chrysin in cancer: Mechanistic perspectives. Toxicol. Lett. 2015, 233, $214-225$. [CrossRef]

27. Ahmed, S.; Othman, N.H. Honey as a potential natural anticancer agent: A review of its mechanisms. Evid. Based Complement. Altern. Med. 2013, 2013, 829070. [CrossRef]

28. Mandal, M.; Jaganathan, S.K. Antiproliferative effects of honey and of its polyphenols: A review. J. Biomed. Biotechnol. 2009, 2009. [CrossRef]

29. Da Silva, P.M.; Gauche, C.; Gonzaga, L.V.; Costa, A.C.O.; Fett, R. Honey: Chemical composition, stability and authenticity. Food Chem. 2016, 196, 309-323. [CrossRef]

30. Saikaly, S.K.; Khachemoune, A. Honey and Wound Healing: An Update. Am. J. Clin. Dermatol. 2017, 18, 237-251. [CrossRef] 
31. Ahmed, S.; Sulaiman, S.A.; Baig, A.A.; Ibrahim, M.; Liaqat, S.; Fatima, S.; Jabeen, S.; Shamim, N.; Othman, N.H. Honey as a potential natural antioxidant medicine: An insight into its molecular mechanisms of action. Oxid. Med. Cell Longev. 2018, 2018, 8367846. [CrossRef] [PubMed]

32. Bucekova, M.; Jardekova, L.; Juricova, V.; Bugarova, V.; Di Marco, G.; Gismondi, A.; Leonardi, D.; Farkasovska, J.; Godocikova, J.; Laho, M.; et al. Antibacterial Activity of Different Blossom Honeys: New Findings. Molecules 2019, 24, 1573. [CrossRef] [PubMed]

33. Wu, N.L.; Fang, J.Y.; Chen, M.; Wu, C.J.; Huang, C.C.; Hung, C.F. Chrysin protects epidermal keratinocytes from UVA- and UVB-induced damage. J. Agric. Food Chem. 2011, 59, 8391-8400. [CrossRef] [PubMed]

34. Debacq-Chainiaux, F.; Leduc, C.; Verbeke, A.; Toussaint, O. UV, stress and aging. Dermatoendocrinol 2012, 4, 236-240. [CrossRef] [PubMed]

35. D'Orazio, J.; Jarrett, S.; Amaro-Ortiz, A.; Scott, T. UV radiation and the skin. Int. J. Mol. Sci. 2013, 14, 12222-12248. [CrossRef] [PubMed]

36. Ohe, W.; Oddo, L.; Piana, M.; Morlot, M.; Martin, P. Harmonized methods of melissopalynology. Apidologie 2004, 35, 18-25. [CrossRef]

37. Ouchemoukh, S.; Amessis-Ouchemoukh, N.; Gómez-Romero, M.; Aboud, F.; Giuseppe, A.; Fernández-Gutiérrez, A.; Segura-Carretero, A. Characterisation of phenolic compounds in Algerian honeys by RP-HPLC coupled to electrospray time-of-flight mass spectrometry. LWT Food Sci. Technol. 2017, 85, 460-469. [CrossRef]

38. Hoff, J.E.; Singleton, K.I. A method for determination of tannis in foods by means of immobilized protein. J. Food Sci. 1977, 42, 1566-1569. [CrossRef]

39. Miliauskas, G.; Venskutonis, P.R.; Van Beek, T.A. Screening of radical scavenging activity of some medicinal and aromatic plant extracts. Food Chem. 2004, 85, 231-237. [CrossRef]

40. Karapetsas, A.; Voulgaridou, G.P.; Konialis, M.; Tsochantaridis, I.; Kynigopoulos, S.; Lambropoulou, M.; Stavropoulou, M.I.; Stathopoulou, K.; Aligiannis, N.; Bozidis, P.; et al. Propolis extracts inhibit UV-induced photodamage in human experimental in vitro skin models. Antioxidants 2019, 8, 125. [CrossRef]

41. Chatatikun, M.; Chiabchalard, A. Phytochemical screening and free radical scavenging activities of orange baby carrot and carrot (Daucus carota Linn.) root crude extracts. J. Chem. Pharm. Res. 2013, 5, 97-102. Available online: www.jocpr.com (accessed on 24 December 2019).

42. Re, R.; Pellegrini, N.; Proteggente, A.; Pannala, A.; Yang, M.; Rice-Evans, C. Antioxidant activity applying an improved ABTS radical cation decolorization assay. Free Radic. Biol. Med. 1999, 26, 1231-1237. [CrossRef]

43. Pellegrini, N.; Re, R.; Yang, M.; Rice-Evans, C. Screening of dietary carotenoids and carotenoid-rich fruit extracts for antioxidant activities applying 2,2'-azinobis(3-ethylenebenzothiazoline-6- sulfonic acid radical cation decolorization assay. Methods Enzymol. 1998, 299, 379-389. [CrossRef]

44. Lee, S.K.; Mbwambo, Z.H.; Chung, H.; Luyengi, L.; Gamez, E.J.; Mehta, R.G.; Kinghorn, A.D.; Pezzutoet, K.M. Evaluation of the antioxidant potential of natural products. Comb. Chem. High Throughput Screen. 1998, 1, 35-46. [PubMed]

45. Olive, P.L.; Banáth, J.P. The comet assay: A method to measure DNA damage in individual cells. Nat. Protoc. 2006, 1, 23-29. [CrossRef]

46. Afaq, F.; Zaid, M.A.; Khan, N.; Dreher, M.; Mukhtar, H. Protective effect of pomegranate-derived products on UVB-mediated damage in human reconstituted skin. Exp. Dermatol. 2009, 18, 553-561. [CrossRef]

47. Amaro-Ortiz, A.; Yan, B.; D'Orazio, J.A. Ultraviolet radiation, aging and the skin: Prevention of damage by topical cAMP manipulation. Molecules 2014, 19, 6202-6219. [CrossRef]

48. Awad, F.; Assrawi, E.; Louvrier, C.; Jumeau, C.; Giurgea, I.; Amselem, S.; Karabina, S.A. Photoaging and skin cancer: Is the inflammasome the missing link? Mech. Ageing Dev. 2018, 172, 131-137. [CrossRef]

49. Han, M.; Bae, J.S.; Ban, J.J.; Shi, H.S.; Lee, D.H.; Chung, J.H. Black rice (Oryza sativa L.) extract modulates ultraviolet-induced expression of matrix metalloproteinases and procollagen in a skin cell model. Int. J. Mol. Med. 2018, 41, 3073-3080. [CrossRef]

50. Barbosa, N.S.; Kalaaji, A.N. CAM use in dermatology. Is there a potential role for honey, green tea, and vitamin C? Complement. Ther. Clin. Pract. 2014, 20, 11-15. [CrossRef]

51. Rodríguez, B.A.; Mendoza, S.; Iturriga, M.H.; Castaño-Tostado, E. Quality parameters and antioxidant and antibacterial properties of some Mexican honeys. J. Food Sci. 2012, 77, C121-C127. [CrossRef]

52. Chua, L.S.; Rahaman, N.L.A.; Adnan, N.A.; Eddie Tan, T.T. Antioxidant activity of three honey samples in relation with their biochemical components. J. Anal. Methods Chem. 2013, 2013, 313798. [CrossRef] [PubMed] 
53. Islam, M.R.; Pervin, T.; Hossain, H.; Saha, B.; Hossain, S.J. Physicochemical and Antioxidant Properties of Honeys from the Sundarbans Mangrove Forest of Bangladesh. Prev. Nutr. Food Sci. 2017, 22, 335-344. [CrossRef] [PubMed]

54. Zalibera, M.; Staško, A.; Šlebodová, A.; Jančovičová, V.; Čermáková, T.; Brezová, V. Antioxidant and radical-scavenging activities of Slovak honeys-An electron paramagnetic resonance study. Food Chem. 2008, 110, 512-521. [CrossRef] [PubMed]

55. Habib, H.M.; Al Meqbali, F.T.; Kamal, H.; Souka, U.D.; Ibrahim, W.H. Bioactive components, antioxidant and DNA damage inhibitory activities of honeys from arid regions. Food Chem. 2014, 153, 28-34. [CrossRef] [PubMed]

56. Kolayli, S.; Can, Z.; Yildiz, O.; Sahin, H.; Karaoglu, S.A. A comparative study of the antihyaluronidase, antiurease, antioxidant, antimicrobial and physicochemical properties of different unifloral degrees of chestnut (Castanea sativa Mill.) honeys. J. Enzym. Inhib. Med. Chem. 2016, 31, 96-104. [CrossRef]

57. Jerković, I.; Marijanović, Z.; Zekić, M.; Tuberoso, C.I.G. First Report on Rare Unifloral Honey of Endemic Moltkia petraea (Tratt.) Griseb. from Croatia: Detailed Chemical Screening and Antioxidant Capacity. Chem. Biodivers. 2017, 14. [CrossRef]

58. Jubri, Z.; Abdul Rahim, N.B.; Aan, G.J. Manuka honey protects middle-aged rats from oxidative damage. Clinics 2013, 68, 1446-1454. [CrossRef]

59. Alzahrani, H.A.; Boukraa, L.; Bellik, Y.; Abdellah, F.; Bakhotmah, B.A.; Kolayli, S.; Sahinet, H. Evaluation of the antioxidant activity of three varieties of honey from different botanical and geographical origins. Glob. J. Health Sci. 2012, 4, 191-196. [CrossRef]

60. Baek, Y.; Kim, Y.J.; Baik, M.Y.; Kim, D.O.; Lee, H. Total phenolic contents and antioxidant activities of Korean domestic honey from different floral sources. Food Sci. Biotechnol. 2015, 24, 1453-1457. [CrossRef]

61. Battino, M.; Giampieri, F.; Cianciosi, D.; Ansary, J.; Chen, X.; Zhang, D.; Gil, E.; Forbes-Hernández, T. The roles of strawberry and honey phytochemicals on human health: A possible clue on the molecular mechanisms involved in the prevention of oxidative stress and inflammation. Phytomedicine 2020. [CrossRef] [PubMed]

62. Cianciosi, D.; Forbes-Hernández, T.Y.; Afrin, S.; Gasparrini, M.; Reboredo-Rodriguez, P.; Manna, P.P.; Zhang, J.; Lamas, L.B.; Flórez, S.M.; Agudo Toyos, P.A.; et al. Phenolic Compounds in Honey and Their Associated Health Benefits: A Review. Molecules 2020, 23, 2322. [CrossRef] [PubMed]

63. Alvarez-Suarez, J.M.; Giampieri, F.; Cordero, M.; Gasparrini, M.; Forbes-Hernández, T.Y.; Mazzoni, L.; Afrin, S.; Beltrán-Ayala, P.; González-Paramás, A.M.; Santos-Buelga, C.; et al. Activation of AMPK/Nrf2 signalling by Manuka honey protects human dermal fibroblasts against oxidative damage by improving antioxidant response and mitochondrial function promoting wound healing. J. Funct. Foods 2016, 25, 38-49. [CrossRef]

64. Ahmad, T.A.F.T.; Jubri, Z.; Rajab, N.F.; Rahim, K.A.; Yusof, Y.A.M.; Makpol, S. Gelam honey protects against gamma-irradiation damage to antioxidant enzymes in human diploid fibroblasts. Molecules 2013, 18, 2200-2211. [CrossRef]

65. Al-Yahya, M.; Mothana, R.; Al-Said, M.; Al-Dosari, M.; Al-Musayeib, N.; Al-Sohaibani, M.; Parvez, M.K.; Rafatullah, S. Attenuation of CCl4-induced oxidative stress and hepatonephrotoxicity by Saudi sidr honey in rats. Evid. Based Complement. Altern. Med. 2013, 2013, 569037. [CrossRef]

66. Cheng, N.; Wu, L.; Zheng, J.; Cao, W. Buckwheat honey attenuates carbon tetrachloride-induced liver and DNA damage in mice. Evid. Based Complement. Altern. Med. 2015, 2015, 987385. [CrossRef]

67. Almasaudi, S.B.; El-Shitany, N.A.; Abbas, A.T.; Abdel-dayem, U.A.; Ali, S.S.; Al Jaouni, S.K.; Harakeh, S. Antioxidant, anti-inflammatory, and antiulcer potential of Manuka honey against gastric ulcer in rats. Oxid. Med. Cell Longev. 2016, 2016, 3643824. [CrossRef]

68. Almasaudi, S.B.; Abbas, A.T.; Al-Hindi, R.R.; El-Shitany, N.A.; Abdel-Dayem, U.A.; Ali, S.S.; Saleh, R.M.; Al Jaouni, S.K.; Kamal, M.A.; Harakeh, S.M. Manuka honey exerts antioxidant and anti-inflammatory activities that promote healing of acetic acid-induced gastric ulcer in rats. Evid. Based Complement. Altern. Med. 2017, 2017, 5413917. [CrossRef]

69. Cheng, N.; Wang, Y.; Cao, W. The Protective Effect of Whole Honey and Phenolic Extract on Oxidative DNA Damage in Mice Lymphocytes Using Comet Assay. Plant. Foods Hum. Nutr. 2017, 72, 388-395. [CrossRef]

70. Alleva, R.; Manzella, N.; Gaetani, S.; Ciarapica, V.; Bracci, M.; Caboni, M.F.; Pasini, F.; Monaco, F.; Amati, M.; Borghi, B.; et al. Organic honey supplementation reverses pesticide-induced genotoxicity by modulating DNA damage response. Mol. Nutr. Food Res. 2016, 60, 2243-2255. [CrossRef] 
71. Afroz, R.; Tanvir, E.M.; Paul, S.; Bhoumik, N.C.; Gan, S.H.; Khalil, M.I. DNA Damage Inhibition Properties of Sundarban Honey and its Phenolic Composition. J. Food Biochem. 2016, 40, 436-445. [CrossRef]

72. Sahhugi, Z.; Hasenan, S.M.; Jubri, Z. Protective effects of gelam honey against oxidative damage in young and aged rats. Oxid. Med. Cell Longev. 2014, 2014, 673628. [CrossRef] [PubMed]

73. Ahmad, I.; Jimenez, H.; Yaacob, N.S.; Yusuf, N. Tualang honey protects keratinocytes from ultraviolet radiation-induced inflammation and DNA damage. Photochem. Photobiol. 2012, 88, 1198-1204. [CrossRef] [PubMed]

74. Haza, A.I.; Morales, P. Spanish honeys protect against food mutagen-induced DNA damage. J. Sci. Food Agric. 2013, 93, 2995-3000. [CrossRef]

75. Živković, L.; Bajić, V.; Dekanski, D.; Čabarkapa-Pirković, A.; Giampieri, F.; Gasparrini, M.; Mazzoni, L.; Potparević, B.S. Manuka honey attenuates oxidative damage induced by $\mathrm{H}_{2} \mathrm{O}_{2}$ in human whole blood in vitro. Food Chem. Toxicol. 2018, 119, 61-65. [CrossRef]

76. Pittayapruek, P.; Meephansan, J.; Prapapan, O.; Komine, M.; Ohtsuki, M. Role of matrix metalloproteinases in Photoaging and photocarcinogenesis. Int. J. Mol. Sci. 2016, 17, 868. [CrossRef]

77. Majtan, J.; Bohova, J.; Garcia-Villalba, R.; Tomas-Barberan, F.A.; Madakova, Z.; Majtan, T.; Majtan, V.; Klaudinyet, J. Fir honeydew honey flavonoids inhibit TNF- $\alpha$-induced MMP-9 expression in human keratinocytes: A new action of honey in wound healing. Arch. Dermatol. Res. 2013, 305, 619-627. [CrossRef]

78. Moskwa, J.; Borawska, M.H.; Markiewicz-Zukowska, R.; Puscion-Jakubik, A.; Naliwajko, S.K.; Socha, K.; Soroczynska, J. Polish Natural Bee Honeys Are Anti-Proliferative and Anti-Metastatic Agents in Human Glioblastoma multiforme U87MG Cell Line. PLoS ONE 2014, 9, e90533. [CrossRef]

(C) 2020 by the authors. Licensee MDPI, Basel, Switzerland. This article is an open access article distributed under the terms and conditions of the Creative Commons Attribution (CC BY) license (http://creativecommons.org/licenses/by/4.0/). 